Studia i Materiały, 2/2016 (21), cz. 1: 96-109

\title{
Przedsiębiorcza orientacja współczesnych polskich korporacji
}

\begin{abstract}
Teresa Piecuch*
We wspótczesnych, coraz bardziej złożonych warunkach otoczenia, przedsiębiorczość postrzegana jest jako wartość sama $w$ sobie. Umożliwia funkcjonowanie i rozwój. Jest podstawa innowacyjności, konkurencyjności, efektywności dziatania. Powinna zatem charakteryzować zarówno jednostki (przedsiębiorczość indywidualna), jak i różnego rodzaju przedsiębiorstwa (przedsiębiorczość korporacyjna, wewnętrzna, intraprzedsiebiorczoś́). Szczególnie pożadana jest $w$ dużych korporacjach, w których pobudzenie „przedsiębiorczego ducha” (,wskrzeszenie” swego rodzaju DNA przedsiębiorczości (Arshi, 2012)) z powodu między innymi formalizacji, biurokracji, braku (lub ograniczonej) wolności działania, jest bardzo trudne (czasami wręcz niemożliwe). Wopracowaniu zwrócono szczególnq uwage na wymiary rozwoju przedsiębiorczości korporacyjnej. Omówiono różnego rodzaju przedsiębiorcze inicjatywy, podejmowane w obrębie struktur dużych, rozbudowanych przedsiębiorstw. Dokonano tego, wykorzystując kategorię przedsiębiorczej orientacji (zbliżonej do przedsiębiorczości, choć nie tożsamej), w której zwraca się uwage na to, jak przedsiębiorstwo funkcjonuje, jakie dziatania podejmuje, by mogto zostać ocenione jako przedsiębiorcze.
\end{abstract}

Słowa kluczowe: przedsiębiorczość, przedsiębiorcza orientacja, korporacja.

Nadesłany: 26.05.2016 | Zaakceptowany do druku: 12.08.2016

\section{Entrepreneurial orientation of contemporary Polish corporations}

In contemporary, more and more complicating conditions of the environment, entrepreneurship is perceived as a value per se. It enables functioning and development. It is the basis for innovativeness, competitiveness and efficiency. Therefore, entrepreneurship should characterize individuals (individual entrepreneurship), as well as various kinds of enterprises (corporate, internal and intra-entrepreneurship). It is particularly desired in large corporations in which the resurrection of "entrepreneurial spirit" (implantation of specific entrepreneurial DNA (Arshi, 2012)), among others, owing to formalization, bureaucracy and lack of freedom is very difficult (sometimes even impossible). In this paper particular attention is paid to the dimensions of corporate entrepreneurship development. There are discussed various types of entrepreneurial activities undertaken within large, complex enterprises. For this purpose, the category of entrepreneurial orientation (similar to entrepreneurship, however not identical) is used. It draws attention to how enterprises function, what actions they take to be considered entrepreneurial.

Keywords: entrepreneurship, entrepreneurial orientation, corporation.

Submitted: 26.05.2016 | Accepted: 12.08.2016

JEL: D, D8, L, L2, L26

Dr Teresa Piecuch - Wydział Zarządzania, Politechnika Rzeszowska.

Adres do korespondencji: Wydział Zarządzania, Politechnika Rzeszowska, Al. Powstańców Warszawy 8, 35-959 Rzeszów; e-mail: piecuch@prz.edu.pl; http://teresapiecuch.sd.prz.edu.pl 


\section{Wprowadzenie}

Przedsiębiorczość jest nastawiona na zmianę i rozwój. Przedsiębiorstwa zdające sobie sprawę $z$ jej znaczenia, wykorzystujące ją w działaniu, zwiększają szanse na sukces, na osiągnięcie i utrzymanie odpowiedniej pozycji konkurencyjnej w danej branży, nawet w coraz bardziej komplikujących się warunkach otoczenia.

Bardzo trudno jest jednoznacznie stwierdzić, jakie przedsiębiorstwo uznać można za przedsiębiorcze. W opracowaniu oparto się na kategorii przedsiębiorczej orientacji, która między innymi opisuje, jak funkcjonują przedsiębiorcze firmy, jakie działania (odróżniające je od innych) podejmują. Różni autorzy formułują różne zestawy wymiarów przedsiębiorczej orientacji, które omówiono w opracowaniu. Najczęściej wymienia się: innowacje, podejmowanie ryzyka, proaktywność, autonomię, strategiczna odnowe, konkurencyjna agresywność, tworzenie w obrębie korporacji nowych, wewnętrznych i/lub zewnętrznych jednostek. W opracowaniu dokonano ich teoretycznej analizy, a także zweryfikowano je z praktyką gospodarowania badanych korporacji. Dokonano tego, opierając się na wynikach badań własnych, zrealizowanych metodą ankietową w 41 różnego rodzaju korporacjach, w których wykorzystano teoretyczny model przedsiębiorczej orientacji opracowany przez autorke, a oparty na 18 wymiarach. Na jego podstawie dokonano oceny przedsiębiorczości badanych korporacji, sformułowano szereg wniosków.

\section{Przedsiębiorczość \\ a przedsiębiorcza orientacja}

Przedsiębiorczość może być rozumiana jako postawa. Oznacza wówczas specyficzne nastawienie do świata, przejawiajace się między innymi skłonnością do podejmowania nowych, ryzykownych wyzwań, umiejętnością dostrzegania i wykorzystywania szans itp. Przedsiębiorczość to także zachowanie, ujawniające się w proaktywnym działaniu nastawionym na zmianę i rozwój, także na racjonalne wykorzystanie posiadanych zasobów (Piecuch, 2013). Pojęcie to może odnosić się zarówno do jednostki (przedsiębiorcy), jak i do różnego rodzaju organizacji (w tym do różnej wielkości przedsiębiorstw). Ma zwiększać szansę na osiągniecie zysku, na poprawę pozycji na rynku - jest integralną częścią zdolności do osiągania sukcesu w coraz bardziej dynamicznym i konkurencyjnym otoczeniu. W przypadku przedsiębiorcy przedsiębiorczość bardzo często odnoszona jest do jego specyficznych cech charakteru ułatwiających podejmowanie przedsiębiorczych inicjatyw, stawianie czoła wyzwaniom i trudnościom; do jego profilu osobowościowego lub innych zmiennych związanych z przedsiębiorca, a istotnych dla jego funkcjonowania w turbulentnym otoczeniu (Cuervo i Ribeiro, Roig, 2016). Najbardziej oczywistym przejawem przedsiębiorczości indywidualnej (odnoszonej do przedsiębiorcy) jest podejmowanie działalności gospodarczej, zakładanie własnych firm. W przypadku przedsiębiorstw przedsiębiorczość może natomiast oznaczać poszukiwanie nowych dostawców, poszerzanie grona odbiorców, dywersyfikowanie działalności, wykorzystywanie nowych strategii i elastycznych form organizacyjnych, wdrażanie innowacji, odnowe struktur przedsiębiorstwa i wiele innych (Alvarez i Busenitz, 2001).

W literaturze przedmiotu przedsiębiorczość (zwłaszcza przedsiębiorczość korporacyjna odnosząca się do rozbudowanych, złożonych struktur różnego rodzaju dużych przedsiębiorstw) często utożsamiana jest z pojęciem „orientacja przedsiębiorcza”, przypisuje się im te same (bądź zbliżone) wymiary warunkujące ich inicjowanie i rozwój. Wielu autorów odróżnia jednak wyraźnie te kategorie. Na przykład G.T. Lumpkin i G.G. Dess, wskazując na różnice między nimi, podkreślają, że (Lumpkin i Dess, 2005):

- przedsiębiorczość zwraca uwage na treść procesu, odpowiada na pytanie „co” jest (co powinno być) realizowane;

- orientacja przedsiębiorcza odnosi się natomiast do tego, ,jak” nowe, kreatywne przedsięwzięcia powinny być realizowane, a zatem do strategii tworzenia procesów, metod i stylów działania przedsiębiorstw, które angażują się w działalność przedsiębiorcza; przedsiebiorcza orientacja odzwierciedla zatem to, jak przedsiębiorstwo działa, a nie to, co robi; określa stopień, w jakim jest ono przedsiębiorcze i zawsze ma to charakter strategiczny.

Orientacja przedsiebiorcza opiera sie na założeniu, że przedsiębiorstwo jako całość może być bardziej (lub mniej) przedsiębiorcze (www.entrepreneurialorientation. 
com, 2016). Jest czymś w rodzaju ideologii organizacyjnej, która generuje strategiczne kryteria ważności, potrzeby legitymizacji, odpowiedniości szans i działań. Kanalizuje i dystrybuuje podejmowanie decyzji w konkretny zestaw procedur i praktyk zarządzania. Dostarcza menedżerom krytycznych informacji na temat tego, w jaki sposób przedsiębiorstwo może skutecznie wykorzystywać procesy, działania przedsiębiorcze dla bardziej efektywnego funkcjonowania dla wzrostu i strategicznej odnowy (www. entrepreneurialorientation.com, 2016).

Orientacja przedsiębiorcza jest silnie zorientowana na rynek, na zachodzące w nim zmiany, pojawiające się trendy (w swojej istocie zbliżona jest zatem do przedsiębiorczego marketingu), by jak najlepiej zaspokajać potrzeby obecnych i przyszłych klientów (Kilenthong, Hultman i Hills, 2016).

Przedsiębiorcza orientacja zapewnia instytucjonalne ramy strategiczne dla zrozumienia sytuacji, które motywuja do działania $\mathrm{i}$ interpretuje ich znaczenie (Bratnicki i Zbierowski, 2005). Wynika to z tego, że wywodzi się $\mathrm{z}$ formułowania, wdrażania i realizacji strategii (a zatem z zarządzania strategicznego); skierowana jest na sukces poprzez wychwytywanie i wykorzystywanie okazji w ramach decyzji strategicznych. Może być rozumiana jako strategia podejmowania praktyk z zakresu zarządzania, które są przedsiębiorcze z natury (Anderson, Kreiser, Kuratko i Hornsby, 2011). To zatem koncepcja łącząca przedsiębiorczość i podejście strategiczne - jak określił to Anderson - powstała „na skrzyżowaniu” przedsiębiorczości i zarządzania strategicznego (Anderson, 2012). Aspekty te są bardzo ściśle ze sobą powiązane. Formułowanie strategii i inne związane $\mathrm{z}$ tym działania obejmują bowiem między innymi: planowanie, analizę podejmowanych decyzji, wiele różnych aspektów funkcjonowania organizacji na poziomie strategicznym - jej system norm, wartości, kulturę, misję itp. Orientacja przedsiębiorcza zaś - bardzo podobnie - jest procesem polegającym na podejmowaniu kluczowych (strategicznych) decyzji, realizowaniu działań umożliwiających sformułowanie przedsiębiorczej wizji i tworzeniu dzięki temu konkurencyjnego potencjału (Lumpkin i Frese, 2015; Lumpkin i Dess, 1996).

\section{Wymiary przedsiębiorczej orientacji}

Przedsiębiorcza orientacja dotyczy całego przedsiębiorstwa, przenika go na różnych szczeblach, dlatego w różny sposób, z wykorzystaniem różnorodnych zmiennych może (powinna) być operacjonalizowana (Wales, 2016). W literaturze przedmiotu odnaleźć można wiele kombinacji wymiarów świadczacych o przedsiębiorczej orientacji korporacji. Prawdopodobnie pierwszy zestaw cech tego typu opracował w roku 1983 roku D. Miller, wskazując na znaczenie (Miller, 1983; Nogalski i Karpacz, 2011; Dyduch, 2006):

- innowacyjności - oznaczającej wdrażanie nowych, oryginalnych produktów; to także stopień, w jakim przedsiębiorstwo tworzy rzeczy nowe, unikatowe, odmienne od konkurentów;

- skłonności do podejmowania ryzyka - cecha ta jest nieodzowna w każdego rodzaju przedsiębiorczości, która sama w sobie jest ryzykowna, jest „... zbiorowym działaniem na zasadzie zarządzania niepewnością poprzez godzenie sprzeczności..." (Bratnicki i Zbierowski, 2005), a wyeliminowanie niepewności i ryzyka we współczesnych procesach gospodarowania (w warunkach permanentnych zmian i agresywnej konkurencji) jest niemożliwe;

- proaktywności - oznaczającej ciągłe poszukiwanie szans, eksperymentowanie z potencjalnymi odpowiedziami na zmieniające się trendy rynkowe; może przejawiać się: w poszukiwaniu nowych możliwości, które mogą, ale nie muszą, być związane $\mathrm{z}$ bieżącą działalnością przedsiębiorstwa, w wyprzedzaniu konkurentów poprzez wprowadzanie nowych produktów i marek, w eliminowaniu działań strategicznych, które znajdują się w fazie dojrzałości lub spadku w cyklu życia.

Zwolennikami podejścia, że w przedsiębiorczej orientacji fundamentalne znaczenie mają trzy wymienione wyżej wymiary, byli także J.G. Covin i D.P. Slevin, którzy twierdzili, że „działają one razem”, tworząc spójną, uniwymiarową orientację strategiczną (Bratnicki i Zbierowski, 2005) - działania innowacyjne $\mathrm{z}$ natury są bowiem dużo bardziej ryzykowne, a z pewnością mogą być zaliczone do zachowań proaktywnych. G.T. Lumpkin i G.G. Dees, opierając się na kla- 
syfikacji D. Millera (oraz na pracach m.in R.A. Burgelmana i I.C. McMillana (Burgelman, 1984; McMillan, 1987)), zmodyfikowali i rozbudowali wymienione przez niego wymiary o jeszcze dwa, tworzac tym samym wielowymiarowy model orientacji przedsiębiorczej. Wyodrebnili oni dodatkowo (Lumpkin i Dess, 1996; Lumpkin i Frese, 2015):

- autonomię - oznaczającą pewien margines swobody, jakiej w swoich działaniach potrzebuja kreatywne jednostki; zachowania intraprzedsiębiorczego pracownika w obrębie korporacji to ciagłe balansowanie pomiędzy konieczną ilością procedur i formalności (których wyeliminować się nie da) a potrzebą wolności i autonomii, koniecznych w przypadku angażowaniu się w przedsiębiorcze (nietypowe) przedsięwzięcia;

- konkurencyjną agresywność - oznaczającą intensywność wysiłku, jaki należy podjąć, by móc skutecznie konkurować, tzn. prześcignąć konkurencję, pełnić funkcję lidera w branży.

Wymieniana przez G.T. Lumpkina i G.G. Deesa konkurencyjna agresywność, była - jako mniej istotna - pomijana na przykład przez D.T. Smarta i J.S. Conanta, natomiast J.G. Covin i D.P. Slevin utożsamiali ten wymiar $\mathrm{z}$ proaktywnością, podkreślając, że przedsiębiorstwo proaktywne jest konkurencyjne - konkuruje agresywnie, dążąc do realizacji celów, używając do tego wszystkich rozsadnych środków, które są w danej chwili dostępne i konieczne (Bratnicki i Zbierowski, 2005), uzyskując tym samym coraz większy udział w rynku. Ich zdaniem proaktywność i konkurencyjna agresywność występują kolejno po sobie - przedsiębiorstwo najpierw bowiem poszukuje atrakcyjnej niszy na rynku (proaktywność), a następnie dąży do jej utrzymania (konkurencyjność), ale wymiary te mogą także występować jednocześnie. G.T. Lumpkin i G.G. Dees zwracali ponadto uwagę na to, że proaktywność jest odpowiedzią przedsiębiorstwa na dostrzeżenie nowych możliwości (szans), a agresywność na zagrożenia (Lumpkin, Dess, 2005; Lumpkin i Dess, 1996).

P. Sharma i J.J. Chrisman zwracają uwagę na znaczenie następujących wymiarów przedsiębiorczej orientacji korporacji (Sharma i Chrisman, 1999; Kuratko i Audretsch, 2009):

- innowacji,
- nowych wewnętrznych i/lub zewnętrznych przedsięwzięć korporacyjnych (Corporate New Venturing) - jest to rodzaj działalności inwestycyjnej prowadzonej przez duże korporacje czy raczej w ich obrębie; chodzi na przykład o tworzenie nowych jednostek (tzw. wewnątrzorganizacyjnych spółek (Pinchot, 1997)), których funkcjonowanie wiąże się $\mathrm{z}$ niepewnością i ryzykiem, ale daje szanse na duży zysk; obejmuje także tworzenie (lub dywersyfikację) nowego produktu, rozwój nowych rynków, komercjalizację nowych technologii lub podejmowanie inicjatyw, których rezultatem jest wdrażanie innowacji ${ }^{2}$,

- strategicznej odnowy - oznaczającej zasadniczą (często radykalną) zmianę podstawowego profilu funkcjonowania przedsiębiorstwa; redefinicję podstawowej jego domeny, wykorzystywanych do tej pory, sprawdzonych przez lata sposobów funkcjonowania; składa się na nią zmiana strategii zarządzania i kluczowych idei, ukierunkowanych na tworzenie organizacji przedsiębiorczej.

C.M. Stopford i Ch.W. Baden-Fuller wyodrębnili typy zjawisk składające się na przedsiębiorczą orientację korporacji (Stopford i Baden-Fuller, 1994):

- tworzenie nowych jednostek gospodarczych w ramach istniejaccych korporacji - obejmuje to wymienione wyżej nowe korporacyjne przedsięwzięcia;

- transformacja lub odnowa już istniejących organizacji poprzez innowacje;

- realizowanie trudnych do osiągnięcia przełomowych, radykalnych, wyjątkowych innowacji zmieniających gruntownie zasady konkurowania w danym sektorze.

W.D. Guth i A. Ginsberg podkreślają natomiast znaczenie tylko dwóch (ale ich zdaniem fundamentalnych, od realizacji których tak naprawdę zależy szereg innych wymiarów, formułowanych przez innych autorów) aspektów istotnych w procesie rozwoju przedsiębiorczej orientacji korporacji (Guth i Ginsberg, 1990):

- innowacji - powodujących wartościowe zmiany w przedsiębiorstwie;

- strategicznej odnowy - powodującej zmiany całego przedsiębiorstwa.

Jak starano się wykazać wyżej, w literaturze można odnaleźć wiele wymiarów istotnych w ocenie przedsiębiorczej orientacji korporacji. W dalszej czéści opracowania oparto się na badaniach własnych 
autorki, w których wykorzystano 18 wymiarów reprezentujących różnego rodzaju działania (także cechy przedsiębiorstwa, sytuacje, zachowania pracowników), które świadczą o przedsiębiorczym charakterze przedsiębiorstw. W ich wyniku starano się skonfrontować skonstruowany wielowymiarowy model (który powstał w wyniku analizy definicji przedsiębiorczości, założeń wielu modeli dotyczących tego zagadnienia, a dostępnych w literaturze przedmiotu, a który jest - co należy wyraźnie podkreślić - subiektywnym konstruktem autorki, która, tworząc model, starała się zawrzeć w nim jak najwięcej wymiarów świadczących o przedsiębiorczości przedsiębiorstwa) $\mathrm{z}$ praktyką gospodarowania poddanych analizie korporacji.

\section{Przedsiębiorcza orientacja wspólczesnych korporacji - aspekt badawczy}

Badaniami dotyczącymi przedsiębiorczej orientacji objęto 41 różnego rodzaju korporacji (czyli dużych, rozbudowanych terytorialnie przedsiębiorstw, zatrudniających powyżej 250 pracowników) funkcjonujących na obszarze całego kraju (choć z siedzibą działalności głównie w południowo-wschodniej Polsce). W większości były to przedsiębiorstwa produkcyjne $(41,02 \%)$, o długim okresie funkcjonowania na rynku (od 21 do 30 lat $-34,15 \%$ oraz powyżej 30 lat - także 34,15\% wskazań), o międzynarodowym zasięgu działalności (aż 75,61\%). Przeprowadzono je w okresie od października 2013 roku do czerwca 2015 roku z wykorzystaniem wystandaryzowanego kwestionariusza ankiety skierowanego do menedżerów pośrednich szczebli zarządzania, np. do kierowników średniego szczebla (nie do kierownictwa naczelnego) $)^{3}$. W tabeli 1 zawarto uwzględnione $\mathrm{w}$ badaniach wymiary wraz $\mathrm{z}$ informacją, które najczęściej występowały w badanych korporacjach (uszeregowano je od najczęściej występujących $)^{4}$.

Jak wynika danych zawartych w tabeli 1 , wymiary świadczące o przedsiębiorczej

Tabela 1. Wymiary przedsiębiorczej orientacji

\begin{tabular}{|l|c|c|}
\hline \multicolumn{1}{|c|}{ Badany wymiar } & TAK (\%) & NIE (\%) \\
\hline 1. Wykorzystywanie nadarzających się okazji (szans) & $\mathbf{9 5}$ & 5 \\
\hline 2. Otwartość na zmiany & $\mathbf{9 3}$ & 7 \\
\hline 3. Wdrażanie różnego rodzaju innowacji & $\mathbf{9 0}$ & 10 \\
\hline 4. Posiadanie przedsiębiorczej i kreatywnej kadry menedżerskiej & $\mathbf{9 0}$ & 10 \\
\hline 5. Zatrudnianie przedsiębiorczych i kreatywnych pracowników & $\mathbf{9 0}$ & 10 \\
\hline 6. Wykorzystywanie innowacyjnych form współpracy z kontrahentami & 88 & 12 \\
\hline 7. Dywersyfikowanie działalności; ciągłe poszerzanie grona odbiorców & 87 & 13 \\
\hline $\begin{array}{l}\text { 8. Wykorzystywanie twórczych metod rozwiązywania problemów, } \\
\text { kreatywnych zespołów pracowników }\end{array}$ & 83 & 17 \\
\hline 9. Wprowadzanie na rynek nowych wyrobów & 82 & 18 \\
\hline $\begin{array}{l}\text { 10. Tworzenie w ramach istniejącej struktury nowych, wewnętrznych } \\
\text { i/lub zewnętrznych jednostek organizacyjnych }\end{array}$ & 82 & 18 \\
\hline 11. Stosowanie nowszych, wydajniejszych maszyn i urządzeń & 80 & 20 \\
\hline $\begin{array}{l}\text { 12. Prowadzenie działań zmierzających do uelastyczniania struktur } \\
\text { organizacyjnych }\end{array}$ & 78 & 22 \\
\hline 13. Podejmowanie ryzyka przez kadrę kierowniczą & 71 & 29 \\
\hline 14. Podejmowanie ryzyka przez pracowników & 68 & $\mathbf{3 2}$ \\
\hline 15. Ograniczanie biurokracji, nadmiernego formalizmu & 67 & $\mathbf{3 3}$ \\
\hline 16. Stosowanie nowszych, doskonalszych metod produkcji & 67 & $\mathbf{3 3}$ \\
\hline 17. Prowadzenie działalności eksportowej & 48 & $\mathbf{4 3}$ \\
\hline 18. Aplikowanie o uzyskanie patentów, licencji, znaków towarowych & $\mathbf{5 2}$ \\
\hline
\end{tabular}

Źródło: opracowanie własne na podstawie przeprowadzonych badań empirycznych. 
orientacji, najczęściej występujące w badanych korporacjach to:

- wykorzystywanie nadarzających się okazji - aspekt ten wystąpił w aż 95\% przypadków (tylko przedstawiciele dwóch na 41 przedsiębiorstw udzielili odpowiedzi przeczacej);

- otwartość na zmiany - 93\% wskazań,

- wdrażanie różnego rodzaju innowacji $90 \%$,

- zatrudnianie przedsiebiorczych i kreatywnych pracowników - 90\%,

- posiadanie przedsiębiorczej i kreatywnej kadry kierowniczej - 90\%.

Badania potwierdziły informacje dostępne w literaturze przedmiotu na temat przedsiebbiorczości - coraz bardziej komplikujace się warunki otoczenia zewnętrznego powodują, że zmiana jest wszechobecna, natomiast by jej sprostać przedsiębiorstwa powinny monitorować otoczenie, wychwytywać pojawiające się w nim szanse i okazje, by móc podążać za zmieniajacymi się warunkami i radzić sobie z nasilającą się wciąż konkurencją. Badania wykazały ponadto, że współczesne korporacje starają się nadążać za zmianami, wdrażając różnego rodzaju innowacje. Bardzo pozytywnie oceniono także kierownictwo i pracowników, którzy są kreatywni i przedsiębiorczy, nie boją się eksperymentować; dzięki którym twórcze działania (będące źródłem innowacji) są inicjowane, a następnie realizowane.

Wymiary zidentyfikowane w najmniejszej liczbie badanych korporacji to:

- aplikowanie o uzyskanie patentów, licencji, znaków towarowych - element ten nie wystapił w $52 \%$ przedsiebiorstw, co odpowiada około 21 korporacjom,

- prowadzenie działalności eksportowej nie wystąpiło w $43 \%$ korporacji,

- stosowanie nowszych, doskonalszych metod produkcji - nie wystąiło w $33 \%$ przypadków,

- ograniczanie biurokracji, formalizmu nie wystąpiło również w 33\% przypadków.

Zawarte wyżej informacje dotyczą przedsiębiorczych wymiarów zidentyfikowanych $\mathrm{w}$ badanych korporacjach. Wymagają one jednak bardziej dokładnej analizy, dlatego w tabeli 2 zawarto stopień ich występowania, który dużo bardziej oddaje rzeczywiste znaczenie danego czynnika. W analizie tej uwzględniono bowiem tylko te korporacje, w których dany element występował (odpowiedzi „tak”). Zastosowanie zatem skali odpowiedzi tak/nie w pierwszym etapie badań umożliwiało wyodrębnienie do dalszych badań tylko tych korporacji, w których dany czynnik wystepował. Tabela ta zawiera także średni stopień występowania badanych wymiarów, a zawarte w niej elementy uszeregowano od największej średniej.

Bardziej dokładna analiza badanych wymiarów wykazała, że w największym stopniu omawiane korporacje:

- zatrudniają pracowników podejmujących ryzyko - wymiar ten uzyskał najwyższą średnią - 4,32; najwięcej pracowników w dużym stopniu podejmowało się realizacji ryzykownych przedsięwzięć, co ciekawe - wymiar ten występował tylko w $68 \%$ korporacji uzyskując jeden z najniższych wyników; szczegółowa analiza wykazała jednak, że stopień jego występowania w korporacjach, w których miał on znaczenie, oceniono bardzo wysoko; - prowadza działalność eksportowa średnia 4,06; najwięcej korporacji realizowało tego typu działalność w bardzo dużym stopniu - 48,5\% wskazań $^{5}$; warto podkreślić, że działalność eksportową prowadziło stosunkowo niewiele korporacji - zaledwie 57\% z nich (wymiar ten uplasował się na przedostatnim miejscu - tabela 1); badania wykazały jednak, że dla tych, które eksportuja swoje produkty (usługi) znaczenie tego elementu było bardzo duże; zatem badane korporacje albo nie eksportowały swoich wyrobów (około $50 \% \mathrm{z}$ nich), albo działalność eksportowa była w nich bardzo ważna (również około 50\% - dopełnienie poprzedniej grupy);

- są otwarte na zmiany - średnia 3,96 ten wymiar pojawił się także w pytaniu ogólnym (tabela 1) na pozycji 2, co potwierdza jego znaczenie w badanych korporacjach.

Powyższe aspekty można uznać za czynniki sprzyjające rozwojowi przedsiębiorczości korporacyjnej.

Najniższą średnią uzyskały patenty i licencje, które zidentyfikowano w najmniejszej liczbie korporacji (48,2\%, to najniższy udział wśród wszystkich badanych przedsiębiorstw). Oznacza to prawdopodobnie, że nie prowadziły one własnych badań, w wyniku których powstają nowe, innowacyjne rozwiązania. Z kolei te korporacje, które wdrażały innowacje, prawdo- 
Tabela 2. Stopień występowania badanych wymiarów i średnie wskazania

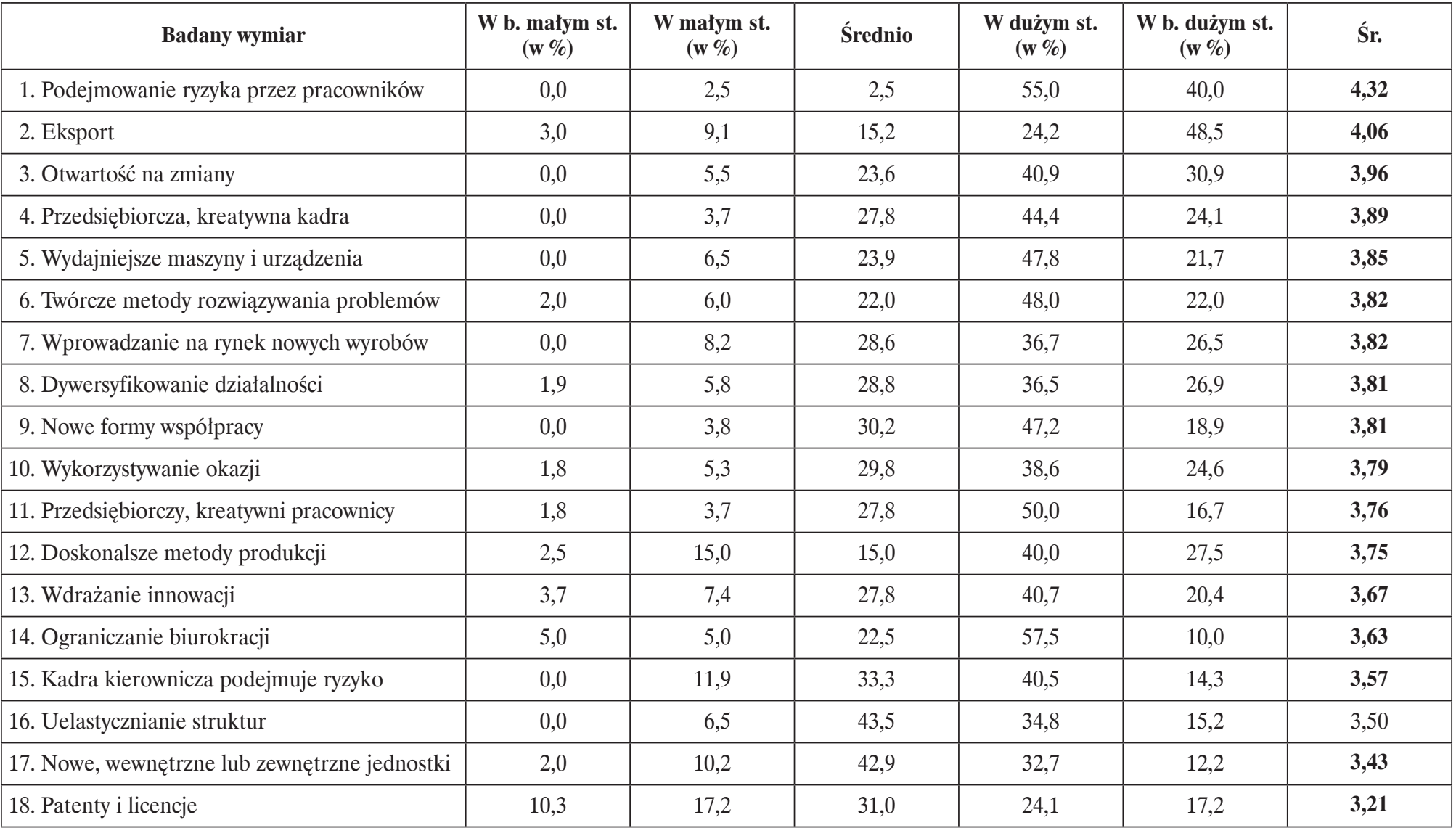

Źródło: opracowanie własne na podstawie przeprowadzonych badań empirycznych. 
podobnie nie korzystały $\mathrm{z}$ własnych badań pochodzących z wewnętrznych, endogenicznych źródeł. W niewielkim stopniu (średnia 3,43 ) w obrębie korporacji tworzono także wewnettrzne lub zewnętrzne jednostki, których celem jest między innymi odchudzanie tradycyjnych, rozbudowanych struktur, które utrudniają realizację przedsiębiorczych inicjatyw, zabezpieczających przed zakłóceniami z zewnątrz. Nie podejmowano także działań mających na celu uelastycznianie wykorzystywanych sztywnych struktur (średnia 3,50), które utrudniają szybkie reagowanie na pojawiające się w otoczeniu impulsy (stają się bardziej przedsiębiorcze), a pracownikom dają możliwość realizacji przedsiębiorczych przedsięwzięć. Wymiary te należy uznać za bariery rozwoju przedsiębiorczości korporacyjnej w badanych jednostkach.

W procesie rozwoju każdego rodzaju przedsiębiorczości, w tym także korporacyjnej, dużą rolę odgrywają innowacje, które sa ich „sercem” (Bratnicki i Zbierowski, 2005). Traktuje się je jako narzędzie w rękach przedsiębiorczych osób, źródło wyższej efektywności, konkurencyjnej przewagi, stymulator rozwoju nie tylko przedsiębiorstw (także całych branż, gospodarek), element walki konkurencyjnej itp. Innowacje postrzega się jako podstawowy aspekt (fundament) procesu przedsiębiorczości, warunek konieczny (choć niewystarczający) uznania przedsiębiorstwa za przedsiębiorcze ${ }^{6}$. Innowacyjność często używana jest jako jedyny miernik przedsiębiorczości - przedsiębiorstwa innowacyjne automatycznie uznawane są za przedsiębiorcze (Bratnicki i Zbierowski, 2005; Saetre, 2001). Ze względu na znaczenie tego wymiaru w rozwoju przedsiębiorczości korporacyjnej spośród badanych elementów wybrano te, które odnoszą się właśnie do wdrażania innowacji (tabela 3). Uszeregowano je według tych, które najczęściej wystepowały w badanych korporacjach.

Innowacje wdrażano w aż $90 \%$ badanych korporacji, choć (jak się okazuje) w niewielkim stopniu - wymiar ten uzyskał bowiem jedną z niższych średnich - 3,67. W tym wypadku (odwrotnie, niż w przypadku eksportu) przedstawiciele znacznej większości badanych korporacji deklarowali, że innowacje są ważne dla ich przedsiębiorstw (że są przez nich wdrażane), ale stopień występowania tego czynnika okazał się niewielki. Najczęściej były to:

- innowacje produktowe - 57\% (48\% wskazań uzyskały innowacje procesowe, $32 \%$ - marketingowe, a najmniej - $25 \%$ - organizacyjne);

- innowacje, które oceniano jako nowości w skali danej korporacji - 38\% wskazań (w $26 \%$ przypadków były to produkty oceniane jako innowacje „w skali kraju”, w $22 \%$ - „w skali świata”, a w 14\% „w skali regionu”).

Wbrew temu, co podkreśla się w literaturze, w grupie badanych korporacji innowacje (innowacyjność) nie odgrywały tak znaczącej roli.

\section{Zakończenie}

Przedmiotem opracowania była przedsiębiorcza orientacja korporacji. Dokonano w nim analizy teoretycznej tej kategorii i jej empirycznej weryfikacji odnoszącej się do 41 przebadanych korporacji funkcjonujacych w południowo-wschodniej Polsce. Informacje dostępne na ten temat w literaturze przedmiotu oraz badania własne

Tabela 3. Wymiary odnoszące się do wdrażania innowacji

\begin{tabular}{|c|c|c|c|c|c|c|c|}
\hline ególnienie & $\begin{array}{c}\text { Tak } \\
(\%)\end{array}$ & 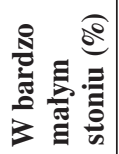 & 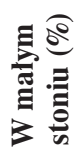 & 总 & 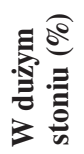 & 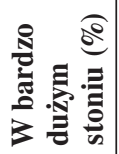 & 兽 \\
\hline Wdrażanie innowacji & 90 & 3,7 & 7,4 & 27,8 & 40,7 & 20,4 & 3,67 \\
\hline Nowe formy współpracy & 88 & 0,0 & 3,8 & 30,2 & 47,2 & 18,9 & 3,81 \\
\hline Wydajniejsze maszyny i urządzenia & 80 & 0,0 & 6,5 & 23,9 & 47,8 & 21,7 & 3,85 \\
\hline Doskonalsze metody produkcji & 67 & 2,5 & 15,0 & 15,0 & 40,0 & 27,5 & 3,75 \\
\hline Patenty i licencje & 48 & 10,3 & 17,2 & 31,0 & 24,1 & 17,2 & 3,21 \\
\hline
\end{tabular}

Źródło: opracowanie własne na podstawie przeprowadzonych badań empirycznych. 
umożliwiły sformułowanie szeregu wniosków (w opracowaniu ograniczono się do zaledwie kilku), miedzy innymi:

- pracownicy badanych korporacji nie unikali ryzyka, chetnie podejmowali się realizacji przedsięwzięć związanych nawet $\mathrm{z}$ bardzo dużym ryzykiem, dużo bardziej ostrożni w tej kwestii okazali się ich przełożeni, którzy zdecydowanie wolą umiarkowane, skalkulowane ryzyko;

- w bardzo dużym stopniu badane korporacje prowadziły działalność eksportową nawet do bardzo odległych krajów; co ciekawe - wymiar ten wystąpił zaledwie w około połowie przedsiębiorstw, ale w tych, w których wystąpił, odgrywał bardzo istotną rolę; badane korporacje podzieliły się zatem na dwie grupy o zbliżonej liczebności - do jednej należą przedsiębiorstwa, które w ogóle nie eksportują, do drugiej te, które prowadzą tego typu działalność w zaawansowanym stopniu;

- badane korporacje były otwarte na zmiany, zdawały sobie sprawę z ich nieuchronności, wszechobecności we współczesnym świecie oraz $\mathrm{z}$ tego, że mogą stanowić impuls do pozytywnych zmian, do poprawy ich sytuacji; we współczesnych warunkach gospodarowania nie ma określeń „stabilność”, „stałość” i korporacje zdają sobie z tego sprawę;

- bardzo popularne w badanej grupie były nowoczesne (innowacyjne) formy współpracy z kontrahentami; we współczesnym świecie ułatwia to kontakty z różnorodnymi interesariuszami, umożliwia osiąganie korzyści z wzajemnej wymiany informacji, transferu wiedzy itp.;

- niewielką wagę w korporacjach przywiązywano także do działań ograniczających biurokrację, formalizm, które uelastyczniłyby wykorzystywane przez nie struktury organizacyjne - wymiary odnoszące się do tych kwestii uzyskały jedne z najniższych średnich.

$\mathrm{Na}$ podstawie powyższych informacji można stwierdzić, że badane korporacje w największym stopniu były (wykorzystując terminologię D. Millera) proaktywne nastawione na zmianę i rozwój oraz skłonne do podejmowania ryzyka. Zdecydowanie mniejszą wagę przywiązywano w nich do wdrażania innowacji, zatem wymiar, którego znaczenie bardzo mocno akcentowane jest $\mathrm{w}$ literaturze, w przypadku badanych przedsiębiorstw nie odgrywał tak dużej roli.

\section{Przypisy}

1 Termin „orientacja przedsiębiorcza” po raz pierwszy został zdefiniowany prawdopodobnie w 1983 r. przez D. Millera, a nastepnie rozwijany był przez J.G. Covina i D.P. Slevina. Jego korzenie sięgają jednak 1973 r. i koncepcji H. Mintzberga dotyczącej podejmowania decyzji strategicznych, w której zwrócił on uwagę na to, że proces ten charakteryzuje się aktywnym poszukiwaniem nowych możliwości w warunkach niepewności, które czesto w sposób dramatyczny wpływają na podejmowane decyzje. Ten aspekt odniesiono następnie do przedsiębiorczości i wykorzystano w przedsiębiorczej orientacji. Duży wkład w rozwój tej kategorii wnieśli także G.T. Lumpkin i G.G. Dess. Na ich publikacjach opiera się większość późniejszych opracowań dotyczących tego zagadnienia (Lumpkin i Frese, 2015; Covin i Slevin, 1984; Rauch, Wiklund, Covin i Wales, 2011; Lumpkin i Dess, 2005; Lumpkin, Dess, 1996; Kilenthong, Hultman i Hills, 2016).

2 Nowe korporacyjne przedsięwzięcia pojawiły się po raz pierwszy w gospodarce Stanów Zjednoczonych, którą uznaje się za ich „ojczyznę”. W latach 1960-1970 jedna czwarta amerykańskich przedsiebiorstw z listy „Fortune 500” posiadała w swoich strukturach korporacyjne firmy. Na początku lat 70. XX w. inicjatywy tego typu zostały zlikwidowane lub zawieszone ze względu na kryzys naftowy i recesję. Powróciły do praktyki gospodarowania w latach 80 . XX w. Od tego czasu stawały się coraz bardziej popularne, głównie w USA i Wielkiej Brytanii. Trzecia faza rozwoju nowych korporacyjnych przedsiewzieć przypadła na lata 90 . XX w. i związana była z boomem rozwojowym nowych technologii, telekomunikacji i Internetu. Obecnie uznaje się je za najbardziej znamienną cechę przedsiębiorczości korporacyjnej. W literaturze zwraca się uwagę na fakt, że nowe korporacyjne przedsięwzięcia powinny powstawać w tzw. niebieskich oceanach. To taki obszar, w którym konkurencja jest niewielka lub nawet jej brakuje. „Jego wody są przejrzyste, czyste, krystaliczne, jasne i bogate w świeże możliwości”. Ich przeciwieństwem jest czerwony ocean, w którym funkcjonuje bardzo wielu konkurentów. „Woda w nim jest mętna, pełna drapieżników i ich ofiar". W takich warunkach w zasadzie nie ma zwycięzców, a trwa tam nieustanna walka o przetrwanie, która nikomu nie przynosi korzyści (Mawson, 2012; Dollinger, 2008; Antoncic i Hisrich, 2001; Block i McMillan, 1995).

3 Kwestionariusz ankiety skierowany był do menedżerów różnych szczebli pośrednich z wyłączeniem najwyższego szczebla zarządzania. Kierownictwo naczelne daje bowiem przyzwolenie na realizacje ryzykownych działań, dostarcza „... ideologicznego i organizacyjnego wsparcia dla aktywności prowadzącej do innowacyj- 
nych przedsięwzięć”, to od nich zależy forma i skala przedsiębiorczości korporacyjnej. Jednak może nie mieć dokładnej wiedzy na temat np. tego, jak zachowują się pracownicy, jakie metody pracy wykorzystują, nie potrafiliby ocenić atmosfery pracy itp. Przystępując do badań, założono, że to od kierownictwa pośrednich szczebli zależy w głównej mierze to, jak będą zachowywali się pracownicy, czy będą pasywni, czy będą wykazywali postawy przedsiębiorcze wykonując swoja prace. Posiadaja oni ponadto odpowiednią wiedzę na temat funkcjonowania korporacji, zarówno o kwestiach dotyczących całej jednostki, jak i podległych im pracowników. Jak podkreślają H.H. Stevenson i J.C. Jarillo, to głównie od menedżerów średniego szczebla, w następnej kolejności od kierowników pierwszej linii, a na końcu od zarzadu zależy, czy w danym przedsiębiorstwie rozwiną się przedsiębiorcze inicjatywy, czy też nie (Dyduch, 2008; Grzegorzewska-Mischka，2010; Stevenson, Jarillo, 1990).

4 Zawarte w tabeli 1 sformułowania odnoszace się do poszczególnych wymiarów stanowiły pytania badawcze zawarte w kwestionariuszu, choć były one dużo bardziej szczegółowo rozpisane; podane były przykłady pewnych działań, zachowań, by ułatwić respondentom sformułowanie odpowiedzi. Niektóre z nich zawierały pytania szczegółowe, by mogli oni lepiej poznać i zrozumieć analizowany wymiar. Na przykład: (1) pytanie odnoszące się do wykorzystywania nadarzających się szans, okazji zawierało przykłady tego typu sytuacji; (2) pytanie dotyczace eksportu zawierało także prośbę o podanie szacunkowego udziału działalności eksportowej, liczby i rodzaju krajów, do których dana korporacja eksportowała swoje wyroby; (3) pytanie o wdrażanie innowacji zawierało ich rodzaj oraz ocenę stopnia nowości (w skali przedsiębiorstwa, regionu, kraju, czy na arenie międzynarodowej) itp

5 Szacunkowy udział działalności eksportowej w tych przedsiębiorstwach był bardzo różny od około $10 \%$ w jednym przypadku do aż $100 \%$, również w przypadku jednej korporacji. Odbiorcami były różne kraje z odległych zakątków świata, np.: Chiny, Izrael, Singapur, Japonia, Rosja i wiele innych; jedna korporacja eksportowała około $50 \%$ swoich wyrobów do aż 50 różnych krajów świata.

6 Rola innowacji w rozwoju przedsiębiorczości (nie tylko korporacyjnej) jest ogromna. W literaturze podkreśla się, że są one narzędziem skutecznej przedsiębiorczości, że z jednej strony można je traktować jako efekt (skutek) zachowań przedsiebiorczych zarówno przedsiębiorców, jak i całych przedsiębiorstw, z drugiej zaś - jako swego rodzaju źródło przedsiebiorczości (wielokrotnie podkreślali to J. Schumpeter i P. Drucker). Opisując zależności między przed- siębiorczością i innowacjami, można stwierdzić, że o ile można wyobrazić sobie przedsiębiorczość bez innowacyjności (nie każda firma jest bowiem innowacyjna, mimo to udaje jej się funkcjonować, osiągać zyski), o tyle nie można wyobrazić sobie innowacyjności bez procesu przedsiębiorczości, w którym nowe rozwiązania znajdują swoje urzeczywistnienie. Innowacje są bowiem zaprzeczeniem rutyny, standardowych sposobów postępowania, powstają w wyniku eksperymentowania, wspiera je twórczość, kreatywność i... właśnie przedsiębiorczość (Piecuch, 2015).

\section{Bibliografia}

Anserson, B.S. (2012). Reconceptualizing Entrepreneurial Orientation: Revisiting a Vital but Troublesome Construct. Academy of Management. Proceedings. Pozyskano z: http://proceedings.aom. org/content/2012/1/1.92.short (03.08.2016).

Anderson, B.S., Kreiser, P., Kuratko, D.F. i Hornsby, J.S. (2011). Attitude behavior, or both? An empirical investigation of the entrepreneurial orientation construct (interactive paper). Frontiers of Entrepreneurial Research, 31(17).

Antoncic, B. i Hisrich, R.D. (2001). Intrapreneurship: Construct: Refinement and Cross-Cultural Validation. Journal of Business Venturing, 16.

Arshi, T. (2012). Entrepreneurial Intensity in the Corporate Sector in Oman: The Elusive Search Creativity and Innovation. International Business Research, 5(9).

Block, Z. i McMillan I.C. (1995). Corporate Venturing. Creating New Business within the firm. Harvard Business School Press.

Bratnicki, M. i Zbierowski, P. (2005). Uwaga i orientacja przedsiębiorcza w gospodarce opartej na wiedzy. Acta Universitatis, Folia Oeconomica, 195

Burgelman R.A. (1984). Designs for corporate entrepreneurship in established firms. California Management Review, 26(3).

Covin, J.G. i Slevin, D.P. (1984). Strategic management of small firms in hostile and benign environments, Strategic Management Journal, 10(1).

Cuervo, A., Ribeiro, D. i Roig, S. (2016). Entrepreneurship: Concepts, Theory and Perspective. Pozyskano z: http://www.uv.es/bcjauveg/docs/LibroCuervoRibeiroRoigIntroduction.pdf (15.04.2016).

Dollinger, M.C. (2008). Entrepreneurship. Strategies and Resources. Illinois, USA: Marsh Publications, Lombard.

Dyduch W. (2006). Badanie poziomu przedsiebiorczości organizacyjnej w polskich firmach. W: M. Romanowska i P. Wachowiak (red.), Koncepcje i narzędzia zarzadzania strategicznego. Warszawa: Oficyna Wydawnicza SGH. 
Dyduch, W. (2008). Pomiar przedsiębiorczości organizacyjnej jako przesłanka podwyższania efektywności. Organizacja i Zarządzanie. Kwartalnik Naukowy Politechniki Ślaskiej, 4. Gliwice: Wyd. Politechniki Śląskiej.

Grzegorzewska-Mischka, E. (2010). Wspótczesne uwarunkowania rozwoju przedsiębiorczości w Polsce. Warszawa: Oficyna Wydawnicza SGH.

Guth, W.D. i Ginsberg, A. (1990). Corporate Entrepreneurship. Strategic Management Journal, 11, Special Issue (Summer).

Kilenthong, P., Hultman, C.H. i Hills, G.E. (2016). Entrepreneurial orientation as the determinant of entrepreneurial marketing behaviors. Journal of Business Strategy, 26(2).

Kuratko, D.F. i Audretsch, D.B. (2009). Strategic Entrepreneurship: Exploring Different Perspectives of an Emerging Concept. Entrepreneurship: Theory and Practice, 33(1).

Lumpkin, G.T. i Dess, G.G. (1996). Clarifying the entrepreneurial orientation construct and linking it to performance. The Academy of Management Review, 21(1)

Lumpkin, G.T. i Dess, G.G. (2005). Linking two dimensions of entrepreneurial orientation to firm performance: the moderating role of environment an industry life cycle. Journal of Business Venturing, 16(5)

Lumpkin, G.T. i Frese, M. (2015). Entrepreneurial orientation and business performance: an assessment of past research and suggestions for the future. Pozyskano z: https://ore.exter.ac.uk/repository/bitstream/handle/10036/4249/rauch.1.pdf? seqence $=12$ (12.02.2015).

Mawson, J. (2012). Corporate Venturing in the UK. RSA Projects, www.thersa.org, (15.01.2016).

McMillan, I.C. (1987). Corporate ventures into industrial markets: Dynamics of aggressive entry. Journal of Business Venturing, 2(1).
Miller, D. (1983). The correlaties of entrepreneurship in three types of firms. Management Science, 29(7).

Nogalski, B. i Karpacz, J. (2011). Komponenty orientacji przedsiębiorczej - studium przypadku. Wspótczesne Zarzadzanie, 3.

Piecuch, T. (2015). Przedsiębiorczość i innowacje w teorii i praktyce funkcjonowania współczesnych przedsiębiorstw. Ekonomika i Organizacja Przedsiębiorstwa, 6 .

Piecuch, T. (2013). Przedsiębiorczość. Podstawy teoretyczne. Warszawa: C.H. Beck.

Pinchot, G. (1997). Tworzenie organizacji o wielu przywódcach. W: F. Hesselbein, M. Goldsmith i R. Beckhard (red.), Lider przysztości. Warszawa: Wyd. Business Press.

Rauch, A., Wiklund, J., Covin, J.G. i Wales, W.J. (2011). The Measurement of Entrepreneurial Orientation. Entrepreneurship. Theory and Practice, $36(4)$.

Saetre, S. (2001). Intrapreneurship. An Exploratory Study of Select Norwegian Industries. Trondheim: Norwegian Research Council.

Sharma, P. i Chrisman, J.J. (1999). Toward a Reconciliation of the Definitional Issues in the Field of Corporate Entrepreneurship. Entrepreneurship. Theory and Practice, Spring.

Stevenson H.H. i Jarillo, J.C. (1990). A paradigm of entrepreneurship: entrepreneurial management, Strategic Management Journal, 11 (Special Issue).

Stopford, C.M. i Baden-Fuller, Ch.W. (1994). Creating Corporate Entrepreneurship. Strategic Management, 15(7).

Wales W. (2016). Entrepreneurial orientation: A review and synthesis of promising research directions. International Small Business Journal, 34. www.entrepreneurialorientation.com, (08.08.2016). 